Nigerian Journal of Physiological Sciences 22 (1-2): 83-87 @Physiological Society of Nigeria, 2007

Available online/abstracted at http://www.biolineinternational.org.br/njps; www.ajol.info/journals.njps; www.cas.org

\title{
HAEMATOPOIETIC PROPERTIES OF ETHANOLIC LEAF EXTRACT OF AGERATUM CONYZOIDES (GOAT WEED) IN ALBINO RATS.
}

\author{
S. O. ITA, *O. E. ETIM, E. E. BEN, *O. F. EKPO \\ Departments of Physiology, *Biochemistry, Faculty of Basic Medical Sciences, \\ College of Health Sciences, University of Uyo, Uyo, Nigeria. \\ Email: uloro2003@yahoo.com
}

\begin{abstract}
Summary: The potential haematological effects associated with the administration of ethanolic leaf extract of Ageratum conyzoides was investigated in rats. 27 rats were randomly divided into four groups. The first group had 6 rats and served as control, the remaining 3 experimental groups and had 7 rats each. These later groups were gavaged with the extract of Ageratum conyzoides in concentrations of $200 \mathrm{mg} / \mathrm{kg}, 400 \mathrm{mg} / \mathrm{kg}$ and $500 \mathrm{mg} / \mathrm{kg}$ respectively for 30days at a dose of $0.1 \mathrm{ml} / \mathrm{body}$ weight. The control group was gavaged with $0.9 \%$ sodium chloride at a dose of $0.1 \mathrm{~m} 1 /$ body weight as placebo. The extract at the doses administered was found to increase in a dose-related fashion PCV and $\mathrm{Hb}(\mathrm{p}<0.01$ for $200 \mathrm{mg} / \mathrm{kg}$ and $\mathrm{p}<0.001$ for $400 \mathrm{mg} / \mathrm{kg}$ and $500 \mathrm{mg} / \mathrm{kg}$ ), $\mathrm{RBC}(\mathrm{P}<0.05$ for $400 \mathrm{mg} / \mathrm{Kg}$ and $500 \mathrm{mg} / \mathrm{kg}$ ) and marginal increases that were not significant $(\mathrm{P}>0.05$ for $200 \mathrm{mg} / \mathrm{kg}) ; \mathrm{MCH}$ and $\mathrm{MCV}(\mathrm{P}<0.05$ and $\mathrm{P}<0.01$ for $400 \mathrm{mg} / \mathrm{kg}$ and $500 \mathrm{mg} / \mathrm{kg}$ respectively) $200 \mathrm{mg} / \mathrm{kg}$ was not significant. MCHC recorded no significant change. WBC recorded marginal increases that were not significant $(\mathrm{P}>0.05)$, similarly, the differential white blood cell recorded marginal increases that were not significant, except lymphocytes that recorded significant increase in group $4(\mathrm{P}<0.05)$. Marginal Decreases in body weight were also observed, these decreases were however not significant. The result of this study thus indicate haematopoietic potentials of the extract and could possibly remedy anaemia.
\end{abstract}

Key Words: Ageratum conyzoides, rats, haemoglobin, white blood cell, haemopoietic potential, anaemia.

\section{Introduction}

Ageratum conyzoides is an annual herbaceous plant with long history of traditional medicinal and agricultural uses in several countries of the world, although its applications varied. It is known to contain many secondary metabolites (Kong et al. 2004). Its efficacy as an antibiotic, anti-inflammatory and analgesic agent have been verified (Durodola, 1977). It is also used as astringent/haemostatic drug for dressing injuries by local farmers in East Africa (Durodola, 1977). Traditional communities in India, Asia, South America and Africa use this herb as a bacteriocide, antidysenteric and antilithic (Almagboul, 1985., Ekundayo, et al, 1988., Borthakur and Baruah, 1997). Oral administration of ethanol extract of Ageratum conyzoides has been reported to exhibit gastroprotective activity via antioxidant, $\mathrm{Ca}^{2+}$ channel blocking and antiserotogenic properties (Achola and Munenge, 1994). Its aqueous leaf extract has however been reported to stimulate gastric acid secretion (Ita, et al, 2005). Multielemental determination in the roots of Ageratum conyzoides, has been reported; the essential elements $\mathrm{K}, \mathrm{Na}, \mathrm{Ca}, \mathrm{Fe}, \mathrm{Mg}, \mathrm{Mn}$ and $\mathrm{Zn}$ and the non-essential elements $\mathrm{Al}, \mathrm{Ba}, \mathrm{Sr}$ and $\mathrm{Rb}$ are present in significant concentrations. Other elements including $\mathrm{Co}, \mathrm{Cr}, \mathrm{Sc}$ and $\mathrm{V}$ are present at trace levels. However the proximate analysis of the leave extract is on going in our laboratory.

Literature concerning the biological activities of this herbaceous plant species relating particularly to possible side effects on the body do not exist. However the prevalent use of this plant in literature and oral claims by our local farmers report that it contain substantial amount of iron along other elements necessitated investigation into the potential effects of repeated administration of ethanolic leaf extract of Ageratum conyzoides on haematological indices in rats and to subsequently evaluate whether its ethnopharmacological uses particularly management of pneumonia, fever and rheumatism may have side effects such as destruction of blood cells, which is common with the use of most chemotherapeutics agents. The degree of anaemia is almost inevitable 
consequence of malaria infection. Although the authors cited did not indicate whether the fever remedy by the extract was due to malaria infection. It is therefore envisage that the result of this investigation may provide a scientific justification for the use of this herb.

\section{Materials and Methods}

A total of twenty seven (27) rats of Wister strain of both sexes weighing $150 \mathrm{~g}-$ $250 \mathrm{~g}$ were randomly assigned to four groups. Group 1 had six animals and served as control. Rats in this group were gavaged with $0.9 \%$ sodium chloride (Normal saline) at $0.1 \mathrm{ml} /$ body weight as placebo for thirty days. While the remaining three groups served as test each containing seven rats; and were gavaged 200, 400 and $500 \mathrm{mg} / \mathrm{kg}$ of $20 \%$ between 80 solution of ethanol extract of Ageratum conyzoides leaves, at a dose $0.1 \mathrm{ml} /$ body weight.

All animals were weighed before the commencement of treatment. While the treatment lasted all animals had free access to drinking water and rat chow (Guinea feeds Nigeria limited, Benin Nigeria). At the end of treatment, all experimental animals were denied their feed and water for 10 hours before they were again weighed and suffocated with chloroform anesthesia. Blood samples were collected by cardiac puncture into EDTA sequestrene bottles.

\section{Determination of haematological indices}

The blood samples collected into EDTA sequestrene bottles were immediately used for determination of haematological indices within 24 hours of sample collection. The haematocrit or packed cell volume was determined according to the haematocrit method described by Alexander and Griffiths (1993a). The haemoglobin concentration in all blood samples were estimated according to the cyanomethaemoglobin method with an absorption maxima at 540nm, as described by Alexander and Griffiths (1993b), while red blood cell, white blood cell and the differential white blood cell counts were estimated according to the visual method of Dacie and Lewis (1991). The Mean corpuscular volume (MCV), Mean Corpuscular hemoglobin concentration (MCHC) and mean Corpuscular Hemoglobin $(\mathrm{MCH})$ were all computed from the values of hemoglobin, packed cell volume and red blood cells obtained.

\section{Statistical analysis}

Statistical analysis were carried out using window SPSS. One way analysis of variance was adopted for comparison, and results were subjected to post hoc test using least square deviation (LSD). The data were expressed as mean \pm standard error. $\mathrm{P}<0.05$ were considered significant.

\section{Results}

The results showed a marginal doserelated declined in body weight of the animals in test groups on the final day, this changes were however not significant $(\mathrm{P}>0.05)$, except group $4(500 \mathrm{mg} / \mathrm{kg})$ that was significantly lower than group $1(\mathrm{P}<0.05)$. The mean values of the $\mathrm{PCV}$, haemoglobin concentration, red blood cell count, MCH, MCHC, MCV, White blood cell count and the differential white blood cell count in control and rats gavaged with ethanolic leaf extract of Ageratum conyzoides are shown in table 1. The test groups 2, 3 and 4 showed significant increases in PCV, total haemoglobin concentration and RBC count that were doserelated. The PCV was significantly lower in the control group, and was compared to the test groups, $(\mathrm{P}<0.01)$ when compared to group 2 $(59.50 \% \pm 1.50),(\mathrm{P}<0.001)$ when compared to groups 3 and 4 animals $(62.21 \% \pm 2.06$ and $71.07 \% \pm 2.98$ respectively). The increase in PCV of rats gavaged with $500 \mathrm{mg} / \mathrm{kg}$ body weight $(71.07 \% \pm 2.98)$, was significantly higher $(\mathrm{P}<0.01)$ than those gavaged with $200 \mathrm{mg} / \mathrm{kg}$ and $400 \mathrm{mg} / \mathrm{kg}$ body weight respectively, table 1 . Increase in haemoglobin $\mathrm{Hb}$ concentration followed the same trend as in PCV, again the increases in test groups were dose dependent. Red blood cell count was not significantly different from control except in groups 3 and 4 gavaged with $400 \mathrm{mg} / \mathrm{Kg}$ and $500 \mathrm{mg} / \mathrm{kg}$ body weight respectively that the increases were significantly higher $(\mathrm{P}<0.05)$ than the control group, increases in test groups were dose dependent and were not significant. The mean Corpuscular haemoglobin (MCH) rises in test groups in a dose related fashion. The increase in $\mathrm{MCH}$ in group 2 was not significantly different from group 1 (control). But groups $3(1.47 \pm 0.06 \mathrm{Pg})$ and $4(1.57 \pm$ $0.05 \mathrm{Pg})$ were significantly $(\mathrm{P}<0.05$ and $\mathrm{P}<0.01)$ respectively) higher than group 1 (control). Mean Corpuscular haemoglobin concentration (MCHC) in both the control and test groups were not statistically significant $(\mathrm{P}>0.05)$. Similarly, the mean corpuscular volume (MCV) was marginally higher in group $2(4.36 \pm$ $\left.0.18 \mu^{3}\right)$ than group 1 (control) $\left(3.86 \pm 0.21 \mu^{3}\right)$, but the increase in group $3\left(4.41 \pm 0.18 \mu^{3}\right)$ and $4\left(4.72 \pm 0.16 \mu^{3}\right)$ were significantly higher than group $1 \quad(\mathrm{P}<0.05$ and $\mathrm{P}<0.001)$ respectively. There were marginal increases of WBC that were dose-related in the test groups, These increases were however not significantly different from group $1 \quad(\mathrm{P}>0.05)$. There were marginal increases in the groups gavaged with 
the extract of Ageratum conyzoides that were dose dependent, again these increases were not significantly different from the control group, except lymphocytes in group 4 that was significantly different from group $1(\mathrm{P}<0.05)$.

Table 1: Haematological indices of control and those gavaged with ethanolic leaf extract of Ageratum conyzoides.

\begin{tabular}{|c|c|c|c|c|c|c|c|c|c|c|c|c|}
\hline Group & $\mathrm{PCV}(\%)$ & $\begin{array}{c}\mathrm{Hb}(\mathrm{g} / \mathrm{dl}) \\
\mathrm{Hb}\end{array}$ & $\begin{array}{c}\mathrm{RBC}(\mathrm{x} / \\
\text { million } \\
\left.\mathrm{mm}^{3}\right)\end{array}$ & $\begin{array}{c}\mathrm{MCH} \\
(\mathrm{Pg})\end{array}$ & $\begin{array}{l}\mathrm{MCH} \\
\mathrm{C}(\%)\end{array}$ & $\begin{array}{c}\mathrm{MCV} \\
\left(\mu^{3}\right)\end{array}$ & $\begin{array}{l}\text { WBC } \\
(\text { cells/ } \\
\left.\mathrm{mm}^{3}\right) \\
\end{array}$ & $\mathrm{N}(\%)$ & $\mathrm{L}(\%)$ & $\mathrm{E}(\%)$ & $\begin{array}{l}\mathrm{M} \\
(\%)\end{array}$ & $\begin{array}{l}\mathrm{B}( \\
\%)\end{array}$ \\
\hline $\begin{array}{l}1 \\
(n=6)\end{array}$ & $\begin{array}{l}48.67 \\
\pm \\
1.91\end{array}$ & $\begin{array}{l}16.23 \\
\pm \\
0.64\end{array}$ & $\begin{array}{l}1.27 \\
\pm \\
0.06\end{array}$ & $\begin{array}{l}1.29 \\
\pm \\
0.07\end{array}$ & $\begin{array}{l}33.34 \\
\pm \\
0.00\end{array}$ & $\begin{array}{l}3.86 \\
\pm \\
0.21\end{array}$ & $\begin{array}{l}5583.33 \\
\pm \\
711.85\end{array}$ & $\begin{array}{l}72.33 \\
\pm \\
4.25\end{array}$ & $\begin{array}{l}36.67 \\
\pm \\
2.39\end{array}$ & $\begin{array}{l}0.50 \\
\pm \\
0.22\end{array}$ & $\begin{array}{l}3.00 \\
\pm \\
0.63\end{array}$ & $\begin{array}{l}0.50 \\
\pm \\
0.22\end{array}$ \\
\hline $\begin{array}{l}2 \\
(n=7)\end{array}$ & $\begin{array}{l}59.50 * * \\
\pm \\
1.50\end{array}$ & $\begin{array}{l}19.83 * * \\
\pm \\
0.50\end{array}$ & $\begin{array}{l}1.42 \\
\pm \\
0.06\end{array}$ & $\begin{array}{l}1.45 \\
\pm \\
0.06\end{array}$ & $\begin{array}{l}33.34 \\
\pm \\
0.00\end{array}$ & $\begin{array}{l}4.36 \\
\pm \\
0.18\end{array}$ & $\begin{array}{l}6971.43 \\
\pm \\
696.40\end{array}$ & $\begin{array}{l}87.86 \\
\pm \\
4.00\end{array}$ & $\begin{array}{l}40.00 \\
\pm \\
3.44\end{array}$ & $\begin{array}{l}1.29 \\
\pm \\
0.38\end{array}$ & $\begin{array}{l}4.29 \\
\pm \\
1.28\end{array}$ & $\begin{array}{l}0.71 \\
\pm \\
0.36\end{array}$ \\
\hline $\begin{array}{l}3 \\
(n=7)\end{array}$ & $\begin{array}{l}62.21 * * * \\
\pm \\
2.06\end{array}$ & $\begin{array}{l}20.88 * * * \\
\pm \\
0.77\end{array}$ & $\begin{array}{l}1.56^{*} \\
\pm \\
0.05\end{array}$ & $\begin{array}{l}1.47 * \\
\pm \\
0.06\end{array}$ & $\begin{array}{l}33.34 \\
\pm \\
0.00\end{array}$ & $\begin{array}{l}4.41 * \\
\pm \\
0.18\end{array}$ & $\begin{array}{l}7714.29 \\
+\quad \\
1725.35\end{array}$ & $\begin{array}{l}92.14 \\
\pm \\
8.60\end{array}$ & $\begin{array}{l}42.14 \\
\pm \\
2.23\end{array}$ & $\begin{array}{l}0.43 \\
\pm \\
0.30\end{array}$ & $\begin{array}{l}3.71 \\
+ \\
0.78\end{array}$ & $\begin{array}{l}1.57 \\
+ \\
0.46\end{array}$ \\
\hline $\begin{array}{l}4 \\
(n=7)\end{array}$ & $\begin{array}{l}71.07 * * * \\
\pm \\
2.98 \mathrm{a}, \mathrm{b}\end{array}$ & $\begin{array}{l}23.69 * * * \\
\pm \\
0,99 \mathrm{~b}, \mathrm{~b}\end{array}$ & $\begin{array}{l}1.53^{*} \\
\pm \\
0.06\end{array}$ & $\begin{array}{l}1.57 * * \\
\pm \\
0.05\end{array}$ & $\begin{array}{l}33.33 \\
\pm \\
0.00\end{array}$ & $\begin{array}{l}4.72 * * \\
\pm \\
0.16\end{array}$ & $\begin{array}{l}8642.86 \\
\pm \\
1529.74\end{array}$ & $\begin{array}{l}95.43 \\
\pm \\
5.76\end{array}$ & $\begin{array}{l}49.57 \\
* \\
\pm \\
2.75 \\
\end{array}$ & $\begin{array}{l}1.00 \\
\pm \\
0.65\end{array}$ & $\begin{array}{l}6.14 \\
\pm \\
0.91\end{array}$ & $\begin{array}{l}1.43 \\
\pm \\
0.11 \\
.8 \\
\end{array}$ \\
\hline
\end{tabular}

$* * *=$ Significantly different from group $1(P<0.001), \quad * *=$ Significantly different from group 1 $(P<0.01), \quad *=$ Significantly different from group $1(P<0.05)$.

$a=$ Significantly different from group $3 \quad(P<0.01), \quad b=$ Significantly different from group 2 $(P<0.01), \quad c=$ Significantly different from group $3(P<0.05)$.

\section{Discussion}

In some parts of the world and indeed Nigeria, local medicinal herbs are employed in the management of various diseases. The erythropoietic value of pumpkin leaf extract for instance have been previously reported (Ajayi et al 2000), sorghum bicolor (Ogwumike 2002). The haematopoietic activities of Ageratum conyzoides has been investigated in this study. The determination of haematological indices provides physiological information on a proper blood assessment in the body. In this study, rats gavaged with ethanolic leaf extract of Ageratum conyzoides recorded significant increases in packed cell volume, haemoglobin concentration, and red blood cell counts. White blood cells were also estimated.

The mean values of the packed cell volume, haemoglobin concentration, red blood cell count, mean corpuscular haemoglobin, mean corpuscular haemoglobin concentration, mean corpuscular volume, white blood cell count and the differential white cell in control and rats gavaged with ethanolic leaf extracts of Ageratum conyzoides are shown in table 1 . The test groups 2, 3 and 4 showed significant increases in PCV, total haemoglobin concentration and $\mathrm{RBC}$ count as compared to the control. The increases in PCV of test groups were significantly different from the control group (i.e. group 1) $(\mathrm{P}<0.01$ for group 2 and $\mathrm{P}<0.001$ for groups 3 and 4 ). Increases that were dose-related were observed in the groups gavaged with Ageratum conyzoides extract. Group $4(500 \mathrm{mg} / \mathrm{kg})$ was significantly higher than groups $2(200 \mathrm{mg} / \mathrm{kg})$ and $3(400 \mathrm{mg} / \mathrm{kg})$ $(\mathrm{P}<0.01)$. There were increases in haemoglobin concentration that followed the same trend as in $\mathrm{PCV}$. There were increases in red blood cell count that were dose-related and were not significant except in groups gavaged with higher doses $(400 \mathrm{mg} / \mathrm{Kg}$ and $500 \mathrm{mg} / \mathrm{kg}$ body weight) of the extract that the increases were significantly higher $(\mathrm{P}<0.05)$ than group 1 (Control). From the foregoing the extract showed an enhanced erythropoietic activity.

The $\mathrm{MCH}$ and MCV also recorded increases in a dose-related fashion. Although, group 2 was not significantly different from group 1 (control), higher dosage showed significant change $(400 \mathrm{mg} / \mathrm{kg}$ and $\mathrm{P}<0.01$ respectively). MCHC recorded no significant change. It is interesting however to note that high dosage of the extract $(400 \mathrm{mg} / \mathrm{kg}$ and $500 \mathrm{mg} / \mathrm{kg}$ ) significantly increase blood parameters such as $\mathrm{PCV}, \mathrm{Hb}$ concentration, $\mathrm{RBC}$ counts, $\mathrm{MCH}$ and $\mathrm{MCV}$. The results of this study is suggestive of the beneficial effects of the herb, Ageratum conyzoides in management of anaemic conditions. Anaemia by definition is a state of lower than normal concentration of haemoglobin that falls below the mean for a normal population to two standard deviations (Ibu, 1999). Normal values 
for male and female are $14 \mathrm{~g} / \mathrm{dl}$ and $12 \mathrm{~g} / \mathrm{dl}$ respectively. Anaemia can also result from low PCV and RBC counts. PCV values below 30\% have been reported to indicate anaemic condition in rats (Chen and Chang, 1981). The least PCV value was recorded in group 2 with a lowest dose of $200 \mathrm{mg} / \mathrm{kg}$ to be $59.50 \pm 1.50 \%$ and there after increase in a dose-related fashion. The ingestion of this extract may possibly be an acceptable blood booster in an anaemic condition targeted at the haematopoietic system. The mechanism of action is however not ascertain, but three possibilities have been postulated, it is possible that Ageratum conyzoides components stimulate the kidney directly to cause formation and secretion of erythropoietin to stimulate haematopoiesis, or could be due to the high iron content of the plant, and if this be the case, it will then lend credence to the earlier report that erythropoietic value of pumpkin leaf extract is the function of the high level of protein, iron and vitamins found in the plant (Ajayi, et al 2000 ). These possibilities are however being investigated in our laboratory.

The WBC counts recorded marginal increases that were not significantly different from group 1 (control) ( $\mathrm{P}>0.05)$. The increases occurred in a dose-related fashion. The slight increase following the gavaged of the extract of Ageratum conyzoides could have been attributed to normal physiologic response of the defense mechanisms following perception of a foreign challenge. The differential white blood cell counts recorded slight increases in the test groups that were not significantly different from group 1 (control) except the lymphocytes that were significantly $(\mathrm{P}<0.05)$ higher in group 4 than group 1. The Marginal increases in white blood cell differential count is suggestive of the antimicrobial property of the herb, Ageratum conyzoides which is consistent with earlier reports of its efficacy as an antibiotic (Durodala, 1977, Borthakur and Baruah, 1987).

It is well known that chemicals, herbs, microorganisms and poisons in tissue response is to some extent species dependent. Consequently, the finding from animal experiment may not be directly interpreted as what might happen in humans, but nevertheless, animals experiment like this provide reliable information of what might happen in humans.

In this work, we observed marked increases in packed cell volume, haemoglobin concentration, coupled with raised red blood cell count that could be aa a result of a direct effect of the extract on the haematopoietic systems. This increase was most pronounce at higher dosage of the extract $(400 \mathrm{mg} / \mathrm{kg}$ and $500 \mathrm{mg} / \mathrm{kg}$ ). It is therefore reported that
Ageratum conyzoides possesses some haematopoietic properties that could possibly remedy anaemia.

\section{Acknowledgement}

The authors are most grateful to Miss Comfort Asukwo, a technologist in-charge of Physiology laboratory, and Mr. Nsikan Malachy of department of Pharmacology and Toxicology, all in University of Uyo for granting us varied forms of technical assistance.

\section{References}

Achola, K. J., Muncenge R. W. and Mwaura. A. M. (1994). Pharmacological Properties of Root and Aerial parts Extracts of Ageratum conyzoides on Isolated ileum and Heart. Fitoterapia. 56: 103 - 109.

Alexander R. R. and Grifiths. J. M. (1993a). Haemotocrit In: Basic Biochemical Methods, $2^{\text {nd }}$ Ed, John Willey and Sons, Inc. Publications. New York, pp. 186 187.

Alexander R. R. and Grifiths. J. M. (1993b). Haemotocrit determination by the cyanomethaemoglobin method In: Biochemical Methods, $2^{\text {nd }}$ Ed, John Willey and Sons, Inc. Publications. New York, pp. $186-187$.

Almagboul., A. Z., Farroq, A. A. and Tyagi, B. R. (1985). Antimicrobial activity of certain Sudanese Plants used in folkloric medicine: Screening for antibacterial activity, Part II. J. Fitoterapia. 56: 103109.

Borthakur, N. and Baruah, AKS, (1987). Search for precocenes in Ageratum conyzoides L. of North-East India. J. Indian Chem. Soc. 64: 540-581.

Chen L. T. and Chang P. K. (1998). Instrasplenic P. A. in Normal Induced Anaemic Rats. Am J. Haematol. 11: 403 407.

Dacie. J. and Lewis S.M. (1991). Practical Hematology London. Churchill, Living stone. pp. 566.

Durodola. J. J. (1977). Antibacterial Poverty of Crude Extracts from Herbal Wound Healing Remedy - Ageratum Conyzoides. Planta Med. 32:388 -390

Ekundayo, O., Sharma, O. S., Rao, E. V. (1988). Essential oil of Ageratum conyzoides . Planta Med. 54: 55-57.

Ibu, J. O. (1999). Synopsis of Medical Physiology $2^{\text {nd }}$ ed, Amazon Press, Manchester pp. 134 - 259.

Ita, S. O., Ettarh R. R., Antai, A. B., Akpogomeh B. A. (2005). The Stimulatory Effect of Intragastric 
Haematopoietic properties of Ageratum conyzoides

Administration of crude Aqueous extract of Ageratum conyzoides on Gastric Acid Secretion in rats. Nigeria Journal of Health and Biomedical Science. 4 (2): $121-124$.

Kong CH, Hu F, Xu XH, Liang WJ, Zhang CX (2004). Allelopathic plants. XV. Ageratum conyzoides L. Allelopathy Journal. 14: 1-12.

Received: 15/3/2007

Accepted:19/9/2007
Ogwumike, O. O. (2002). Hemopoietic effect of aqueous extract of the leaf sheath of sorghum bicolor in albino rats. African Journal of Biomedicl Research. 5:69-71.

O. I. Ajayi, T. C. Ajayi, E. U. Omokaro and N. K. D. Halim (2000). Erythropoietic value of pumpkin leaf extract (Telfaira occidentalis) in rabbits- a preliminary study. Nigerian Journal of Physiological Sciences 16 (1-2): 1-3. 